\title{
Phylogeny and morphology of Anthracoidea pamiroalaica sp. nov. infecting the endemic sedge Carex koshewnikowii in the Pamir Alai Mts (Tajikistan)
}

\author{
Marcin Piątek $^{1}$ - Matthias Lutz ${ }^{2} \cdot$ Marcin Nobis $^{3} \cdot$ Arkadiusz Nowak $^{4}$
}

Received: 24 July 2015 /Revised: 16 October 2015 / Accepted: 2 November 2015 /Published online: 28 November 2015

(C) The Author(s) 2015. This article is published with open access at Springerlink.com

\begin{abstract}
A novel Anthracoidea species, A. pamiroalaica on the endemic sedge Carex koshewnikowii, is described and illustrated from the Pamir Alai Mts in Tajikistan (Central Asia). The new species is phenotypically nearly identical with Anthracoidea sempervirentis, but clearly divergent genetically. Phylogenetic analyses based on LSU sequences showed affinity of Anthracoidea pamiroalaica to A. baldensis, A. rupestris, $A$. capillaris, and $A$. vankyi infecting host sedges in different Carex sections (Baldenses, Rupestres, Chlorostachyae, and Phaestoglochin, respectively), but not to A. misandrae, and A. sempervirentis, two sequenced species parasitic on host species from the section Aulocystis. This phylogenetic placement is briefly discussed in the context of Anthracoidea evolution.
\end{abstract}

Keywords Anthracoidea · Carex · Central Asia · Cryptic species $\cdot$ Plant pathogens $\cdot$ Smut fungi $\cdot$ Ustilaginales

Section Editor: Dominik Begerow

Marcin Piątek

m.piatek@botany.pl

1 Department of Mycology, W. Szafer Institute of Botany, Polish Academy of Sciences, Lubicz 46, PL-31-512, Kraków, Poland

2 Plant Evolutionary Ecology, Institute of Evolution and Ecology, University of Tübingen, Auf der Morgenstelle 5, D-72076 Tübingen, Germany

3 Department of Plant Taxonomy, Phytogeography and Herbarium, Institute of Botany, Jagiellonian University, Kopernika 27, PL-31501, Kraków, Poland

4 Laboratory of Geobotany and Plant Conservation, Department of Biosystematics, Opole University, Oleska 48, PL-45-052, Opole, Poland

\section{Introduction}

The genus Anthracoidea Bref., typified by Anthracoidea caricis (Pers.) Bref., includes smut fungi infecting host plants in the Cyperaceae (mostly species of Carex L.), forming globoid sori in the ovaries and having spores produced directly on the outer surface of the reduced achenes (Kukkonen 1963; Vánky 2002). The species delimitation traditionally was based on comparative morphology and phenotypic differences between Anthracoidea species attacking host plants within a particular Carex section (Nannfeldt 1979; Vánky 1979, 2012). The first molecular phylogenetic study using LSU rDNA sequences including 28 Anthracoidea species (and two undescribed species), mainly from Europe, confirmed most of the analysed species (Hendrichs et al. 2005) and established a sound phylogenetic backbone for molecular work on Anthracoidea. The phylogenetic hypothesis presented by Hendrichs et al. (2005) can now be completed by the remaining described and potentially undescribed species. Since that study, only one additional Anthracoidea species was included in molecular phylogenetic analyses, namely the new species A. caricis-meadii K.G. Savchenko, M. Lutz \& Piątek (Savchenko et al. 2013). The currently recognized biodiversity of Anthracoidea includes 110 species (Denchev and Denchev 2011a, b, 2012; He et al. 2011; Vánky and Abbasi 2011; Piątek 2012, 2013, 2014; Vánky 2012; Denchev et al. 2013; Savchenko et al. 2013), representing the largest species diversity among smut genera attacking cyperacean hosts.

The biodiversity of Anthracoidea species is, however, probably much higher than currently recognized. Novel species may be detected by disentangling polyphagous species that are likely species complexes, or they could be discovered on so far unknown host plants and in poorly surveyed ecoregions. The mountains of Central Asia are a promising area to search for unknown Anthracoidea species since they 
are rich in potential host plants, the Carex species, and are relatively poorly surveyed for these smuts compared to, e.g., Europe. For example, the checklist of Tajik fungi (Korbonskaya 1990) contains seven Anthracoidea species that may, in most part, be wrongly identified considering the reported host plants. That this region may still hide undescribed species can be supported by the recent description of the new species Anthracoidea mulenkoi Piatek from Pakistan (Piątek 2006) or A. melanostachyae Denchev \& T.T. Denchev from Iran and Tajikistan (Denchev and Denchev 2011b).

Carex koshewnikowii Litv. belongs to the section Aulocystis Dumort. subsect. Lanatae T.V. Egorova (1999). It is an endemic species with a small distribution area, occurring in Kyrgyzstan in the southwestern Tian Shan Mts (Egorova 1999; Lazkov and Sultanova 2011) and in Tajikistan in the Zeravshan Mts, Hissar Mts, Darvaz Mts, and Pamir Mts (Krachetovich 1963; Egorova 1999; Nobis et al. 2011). The south Pamirian specimens of that species need to be revised, to avoid intermingling with Carex koshewnikowii subsp. chitralensis (Nelmes) Dickoré, an intraspecific taxon occurring in northeastern Afghanistan (Breckle et al. 2013). Carex koshewnikowii is a member of the chasmophytic flora of the Pamir Alai and Tian Shan Mts, which in that area consists of many taxa of rock habitats that are geographically restricted to Tajikistan and its closest vicinities (Nobis et al. 2013; Nowak et al. 2014a, b, c, d).

In the course of systematic studies on vegetation and vascular plants of the Pamir Alai Mts in Tajikistan several specimens of Carex koshewnikowii infected by the ovariicolous smut of the genus Anthracoidea were found in the Takob river valley of the Hissar Mts in 2012 and 2015. So far, Carex koshewnikowii has not been reported to harbour any Anthracoidea species nor any other smut fungus. Although Carex koshewnikowii is very common in the Pamir Alai Mts, only one infected population was observed in the period of many years of field work. The collected specimens were phenotypically similar to Anthracoidea sempervirentis Vánky, a species originally described from Carex sempervirens Vill. (type host; see Vánky 1979), and currently reported from 12 host sedges of the section Aulocystis Dumort. (= Frigidae Fr. ex Kük.) in Europe and East Asia (Vánky 2012; Denchev et al. 2013). However, recent molecular studies revealed that many morphologically defined polyphagous smuts and false smuts in fact represent complexes of host-specific independent cryptic or pseudocryptic species (Vánky and Lutz 2007; Bauer et al. 2008; Lutz et al. 2005, 2008; Piątek et al. 2011, 2012, 2013a, b; Savchenko et al. 2014a, b; Vasighzadeh et al. 2014) and, therefore, Anthracoidea found on Carex koshewnikowii could be a species different than Anthracoidea sempervirentis. Thus, this study aims to resolve the systematic placement of Anthracoidea on Carex koshewnikowii using light and scanning electron microscopy and phylogenetic analyses using LSU rDNA sequences.

\section{Materials and methods}

\section{Morphological analyses}

Sori and spore characteristics were studied using dried herbarium material. Specimens were examined by light microscopy (LM) and scanning electron microscopy (SEM). For LM, small pieces of sori were mounted in lactic acid, heated to boiling point and cooled, then examined under a Nikon Eclipse 80i light microscope. LM micrographs were taken with a Nikon DS-Fil camera. Spores were measured using NIS-Elements BR 3.0 (Nikon) imaging software. Spores were measured in plane view and measurements were adjusted to the nearest $0.5 \mu \mathrm{m}$. Spore size ranges were assigned to one of the three groups distinguished by Savile (1952): (1) smallsized spores-13-21(-23) $\times 9-17(-20) \mu \mathrm{m}$; (2) mediumsized spores $-15-25(-27) \times 10-21 \mu \mathrm{m}$; (3) large-sized spores - 18-33×13-28 $\mu \mathrm{m}$. For SEM, spores taken directly from dried herbarium samples were dusted onto carbon tabs and fixed to an aluminium stub with double-sided transparent tape. The stubs were sputter-coated with carbon using a Cressington sputter-coater and viewed under a Hitachi S-4700 scanning electron microscope, with a working distance of ca. $12 \mathrm{~mm}$. SEM micrographs were taken in the Laboratory of Field Emission Scanning Electron Microscopy and Microanalysis at the Institute of Geological Sciences of Jagiellonian University (Kraków).

\section{DNA extraction, PCR, and sequencing}

Genomic DNA was isolated directly from the holotype specimen (KRA F-2012-146). For methods of isolation and crushing of fungal material, DNA extraction, amplification, purification of PCR products, sequencing, and processing of the raw data see Lutz et al. (2004) and Savchenko et al. (2013). The 5'-end of the nuclear large subunit ribosomal DNA (LSU) was amplified using the primer pair NL1 and NL4 (O'Donnell 1993). The LSU sequence obtained in this study was deposited in GenBank (accession number KT006854).

\section{Phylogenetic analyses}

In addition to the LSU sequence of Anthracoidea sp. on Carex koshewnikowii newly obtained in this study, sequences of all other species of Anthracoidea available in GenBank were used for molecular phylogenetic analyses (Hendrichs et al. 2005; Bauer et al. 2006; Begerow et al. 2007; Savchenko 
et al. 2013). Methods of sequence alignment, handling of the alignment, and rooting of the trees followed Savchenko et al. (2013) with the following options for GBlocks 0.91b (Castresana 2000): "Minimum Number of Sequences for a Conserved Position" to 30, "Minimum Number of Sequences for a Flank Position" to 30, "Maximum Number of Contiguous Non-conserved Positions" to 8, "Minimum Length of a Block" to 5, and "Allowed Gap Positions" to "With half". The resulting alignment was used for phylogenetic analyses using a Bayesian Approach (BA) and Maximum Likelihood (ML). For BA, a Markov chain Monte Carlo technique was used as implemented in the computer program MrBayes 3.1.2 (Huelsenbeck and Ronquist 2001; Ronquist and Huelsenbeck 2003). Four incrementally heated simultaneous Markov chains were run over 5,000,000 generations using the general time reversible model of DNA substitution with gamma distributed substitution rates and estimation of invariant sites, random starting trees and default starting parameters of the DNA substitution model as recommended by Huelsenbeck and Rannala (2004). Trees were sampled every 100th generation, resulting in an overall sampling of 50,001 trees. From these, the first 5001 trees were discarded (burn-in=5001). The trees sampled after the process had reached stationarity (45,000 trees) were used to compute a $50 \%$ majority rule consensus tree in order to obtain estimates for the a posteriori probabilities of groups of species. This Bayesian approach to phylogenetic analyses was repeated five times to test the independence of the results from topological priors (Huelsenbeck et al. 2002). ML analysis (Felsenstein 1981) was conducted with the RAxML 7.2.6 software (Stamatakis 2006), using raxmlGUI (Silvestro and Michalak 2010), invoking the GTRCAT and the rapid bootstrap option (Stamatakis et al. 2008) with 1000 replicates.

\section{Results}

\section{Phylogenetic analyses}

The different runs of the BA that were performed and ML analyses yielded consistent topologies with respect to well-supported branches. To illustrate the results, the consensus tree of one run of the BA is presented (Fig. 1). In all analyses, the Anthracoidea specimen from Carex koshewnikowii clustered within a clade that included Anthracoidea baldensis Vánky, A. capillaris Kukkonen, A. caricis, A. caricis-albae (Syd.) Kukkonen, $A$. globularis Kukkonen, A. irregularis (Liro) Boidol \& Poelt, A. rupestris Kukkonen, and A. vankyi Nannf. (fourth group after Hendrichs et al. 2005) as sister lineage of $A$. baldensis and $A$. rupestris, but with huge distance to A. sempervirentis.

\section{Taxonomy}

Anthracoidea pamiroalaica Piątek, M. Lutz \& M. Nobis, sp. nov. Figs. 2d, e, and 3

MycoBank \# MB 814814

Etymology: In reference to the main Middle Asian Pamir Alai Mountain System, the type locality area of the new species, with abundant occurrence of the host plant Carex koshewnikowii.

Type: Tajikistan, Pamir Alai Mts: Hissar Mts, Takob river valley, on rocks, exp. SE, slope $80^{\circ}, 38^{\circ} 49^{\prime} 57^{\prime \prime} \mathrm{N}, 68^{\circ} 52^{\prime} 08^{\prime \prime} \mathrm{E}$, elev. ca. 1350 m a.s.l., on Carex koshewnikowii, 8 June 2012, M. Nobis \& A. Nowak (holotype: KRA F-2012-146; GenBank: KT006854)._Paratype: Tajikistan, Pamir Alai Mts: Hissar Mts, Takob river valley, on rocks, exp. SE-E, slope $70-85^{\circ}, 38^{\circ} 49^{\prime} 57^{\prime \prime} \mathrm{N}, 68^{\circ} 52^{\prime} 08^{\prime \prime} \mathrm{E}$, elev. ca. 1350 m a.s.1., on Carex koshewnikowii, 31 May 2015, M. Nobis \& A. Nowak (KRA F-2015-1, KRAM F-57734).

Description: Parasitic on Carex koshewnikowii. Sori in single ovaries of the inflorescences, usually one, but exceptionally two or three sori per inflorescence, forming black, globose bodies around achenes, about 2-4 $\mathrm{mm}$ in diameter, twice to three times as large as healthy achenes, enclosed by a whitish membrane (thin layer of host epidermis) that ruptures to reveal agglutinated spores, powdery on the surface, sori partly hidden by the perigynium. Spores medium-sized, irregularly flattened, yellow-brown, brown to reddish-brown, irregularly globose, subglobose, broadly ellipsoidal or polyangularly rounded, $(15.0-) 16.0-24.0(-25.0) \times(13.0-) 14.0-19.5(-21.0)$ $\mu \mathrm{m}$, av. $\pm \mathrm{SD}, 19.4 \pm 2.2 \times 16.6 \pm 1.6 \mu \mathrm{m}, n=150 / 2$ $[(15.0-) 16.0-23.5(-25.0) \times(13.0-) 14.0-19.5 \mu \mathrm{m}$, av. $\pm \mathrm{SD}$, $18.9 \pm 2.1 \times 16.4 \pm 1.6 \mu \mathrm{m}, n=100$, for the holotype; 17.0 $24.0 \times(14.5-) 15.0-18.5(-21.0) \mu \mathrm{m}$, av. \pm SD, $20.4 \pm 2.2 \times$ $16.9 \pm 1.5 \mu \mathrm{m}, n=50$, for the paratype], rarely enclosed by a thin, hyaline, mucilaginous sheath; wall even, 1.0-2.5 $\mu \mathrm{m}$ thick, somewhat darker than the rest of spore, thicker at the angles, without internal swellings and protuberances, occasionally with light refractive spots; surface finely verruculose as seen by LM, spore profile almost smooth or finely wavy, surface finely verruculose as seen by SEM, with low warts up to $0.5 \mu \mathrm{m}$ high (measured from SEM micrographs), warts usually single, rarely confluent, interspaces from almost smooth to finely punctate.

Ecology: At the type locality, Anthracoidea pamiroalaica grows abundantly on its host species Carex koshewnikowii in the Takob river valley, within the Hissar Mts (the western Hissaro-Darvasian geobotanical subregion). Carex koshewnikowii occurs there mainly in the association of Dionysietum involucratae A. Nowak, M. Nobis, S. Nowak \& A. Nobis (Nowak et al. 2014a). It grows on granite rocks of a relatively low cohesion index and acidity ( $\mathrm{pH} 6.0$ to 6.5) on rock faces, mainly on SW-S-SE-E aspects with almost 
Fig. 1 Bayesian inference of phylogenetic relationships within the sampled Anthracoidea species: Markov chain Monte Carlo analysis of an alignment of LSU base sequences using the $\mathrm{GTR}+\mathrm{I}+\mathrm{G}$ model of DNA substitution with gamma distributed substitution rates and estimation of invariant sites, random starting trees, and default starting parameters of the DNA substitution model. A $50 \%$ majority-rule consensus tree is shown computed from 45,000 trees that were sampled after the process had reached stationarity. The topology was rooted with sequences of Anthracoidea carphae, A. curvulae, A. elynae, and $A$. sclerotiformis. Numbers on branches before slashes are estimates for a posteriori probabilities, numbers on branches after slashes are ML bootstrap support values. Branch lengths were averaged over the sampled trees. They are scaled in terms of expected numbers of nucleotide substitutions per site. A. = Anthracoidea

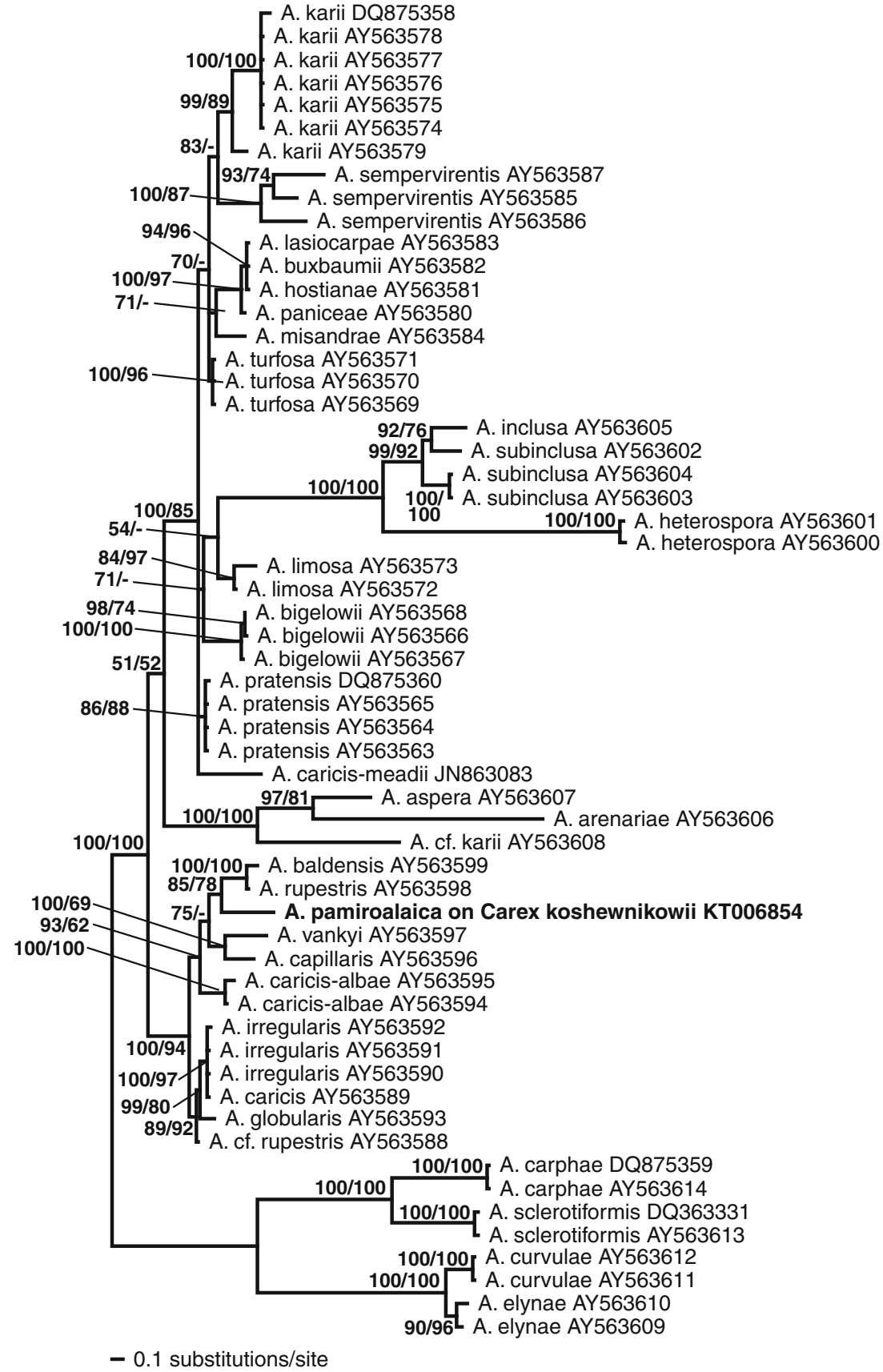

vertical, or even overhanging, inclinations, the approximate mean being $100^{\circ}$ (Fig. 2a, b, c).

\section{Discussion}

The phylogenetic relations between Anthracoidea species resolved in the current study are congruent with those resolved by the Bayesian Approach (BA) of Hendrichs et al. (2005), and, although based on sequences from only one rDNA region (LSU), most branches of the phylogenetic tree are well supported. Thus, in line with Hendrichs et al. (2005), this study confirms that LSU is, in most cases, suitable to delimit Anthracoidea species and to a lesser extent to infer phylogenetic relations between species. Only a few species cannot be separated using LSU sequences (Anthracoidea caricis and A. irregularis, as well as A. buxbaumii Kukkonen, A. hostianae B. Lindeb. ex Nannf., A. lasiocarpae B. Lindeb. ex Kukkonen and A. paniceae Kukkonen; see also Hendrichs et al. 2005; Savchenko et al. 2013) and probably more sensitive genes should be sequenced to delimit those species pairs genetically though they still could be well separated phenotypically or ecologically (Piatek and Mułenko 2010; Vánky 2012). However, considering the predominance 

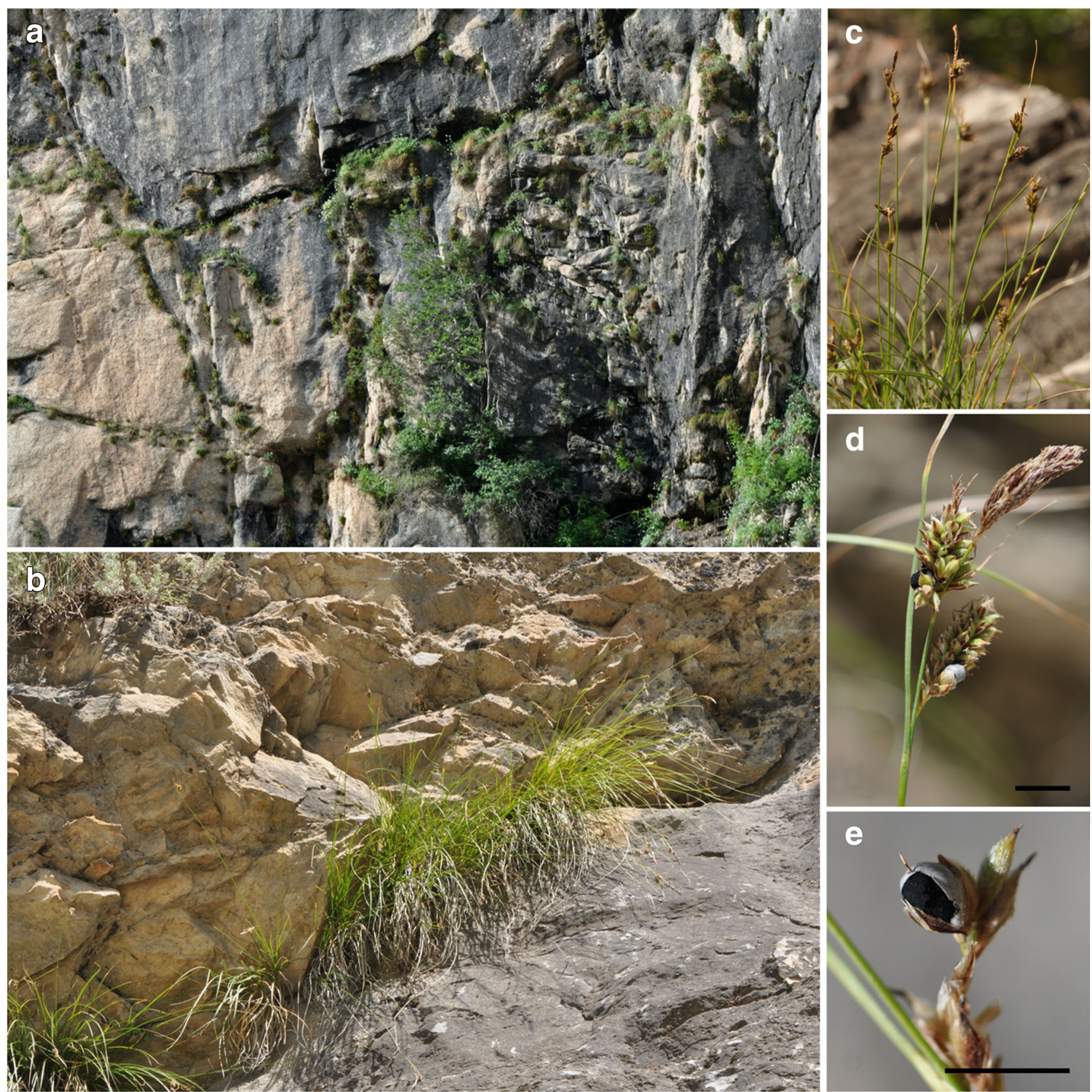

Fig. 2 Anthracoidea pamiroalaica on Carex koshewnikowii: a type locality area in the Takob river valley in the Hissar Mts (Tajikistan), b-c general habit of healthy Carex koshewnikowii, $\mathbf{d}-\mathbf{e}$ sori in the ovaries of Carex koshewnikowii. Scale bars: $\mathbf{d}-\mathbf{e}=5 \mathrm{~mm}$

of LSU sequences (57 sequences) compared to ITS sequences (three sequences) or SSU sequences (two sequences) of Anthracoidea species deposited in GenBank (as checked on 6 June 2015), we recommend the LSU for molecular systematics and phylogeny of Anthracoidea.

The striking macroscopic character of the Anthracoidea specimens on Carex koshewnikowii is the development of relatively large sori, which are twice or three times larger than healthy achenes, though this character alone may not be suitable to delimit the species. Considering micro-morphological characters, Anthracoidea on Carex koshewnikowii could be compared with other Anthracoidea species known on sedges from the section Aulocystis (sensu Egorova 1999): A. altera Nannf., A. disciformis (Liro) Piątek, A. misandrae Kukkonen, A. sempervirentis, A. setosae L. Guo, and A. stenocarpae Chleb. Of them, A. altera, A. disciformis, and A. stenocarpae have smaller spores (up to $21 \mu \mathrm{m}$ long) with regular shape; additionally, $A$. altera and $A$. stenocarpae have weak internal swellings and thinner spore walls (up to $1.5 \mu \mathrm{m}$ thick), and $A$. disciformis has papillate spores enclosed by a 

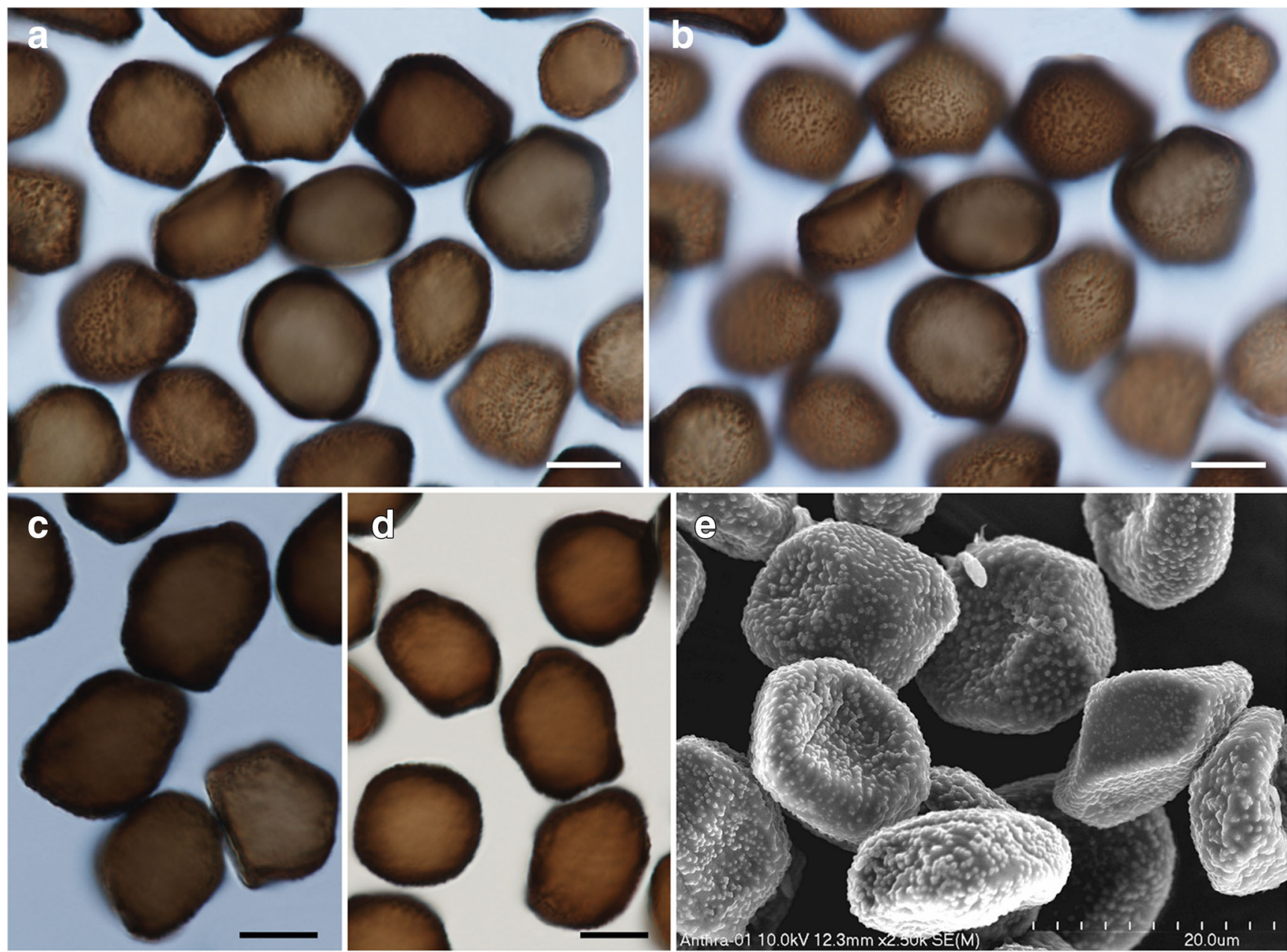

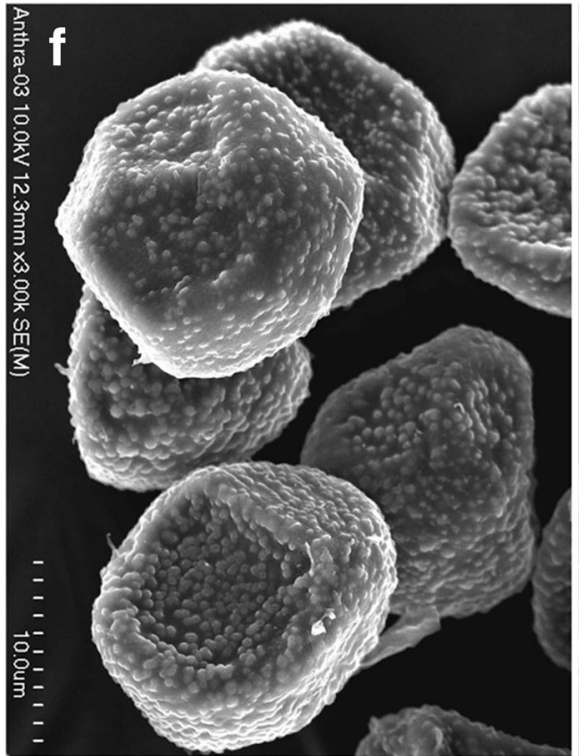

Fig. 3 Anthracoidea pamiroalaica on Carex koshewnikowii (all from KRA F-2012-146): a-d spores seen by light microscopy, median (a, c-d), and superficial (b) views, $\mathbf{e}-\mathbf{g}$ spores seen by scanning

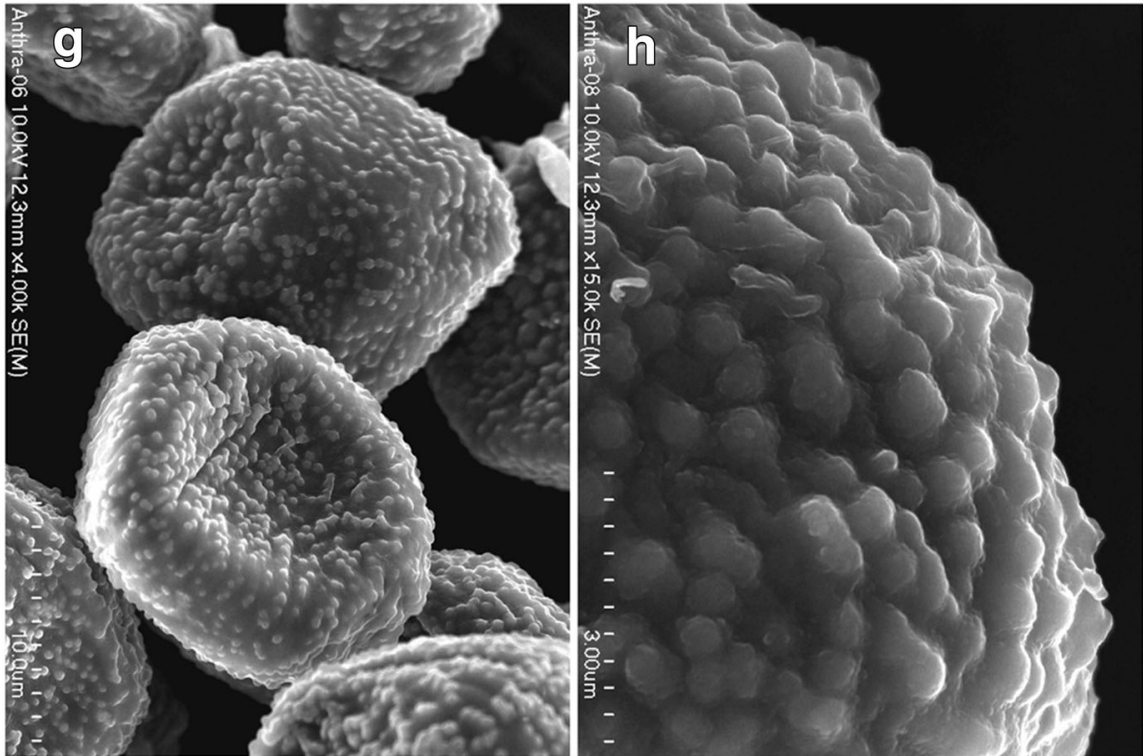

electron microscopy, $\mathbf{h}$ spore wall ornamentation seen by scanning electron microscopy. Scale bars: $\mathbf{a}-\mathbf{d}, \mathbf{f}-\mathbf{g}=10 \mu \mathrm{m}, \mathbf{e}=20 \mu \mathrm{m}, \mathbf{h}=3 \mu \mathrm{m}$

koshewnikowii is similar to A. misandrae and A. setosae, but both of them differ in having spores with more regular shape, 
thinner spore walls (up to $1.5 \mu \mathrm{m}$ thick), and a somewhat different ornamentation (Vánky 2012). In spore size and morphology, Anthracoidea on Carex koshewnikowii is nearly identical with A. sempervirentis, and differs only in having a more distinctively developed ornamentation (for SEM illustrations of spore ornamentation of $A$. sempervirentis on type host Carex sempervirens, see Piątek 2005b; Piątek et al. 2005; Vánky 1994, 2012). More important, Anthracoidea on Carex koshewnikowii and A. sempervirentis are separated by a considerable genetic distance and cluster in two divergent Anthracoidea subclades (Fig. 1). This supports our initial hypothesis that, although phenotypically similar, the specimens on Carex koshewnikowii are not conspecific with A. sempervirentis, and are accordingly assigned to the novel species Anthracoidea pamiroalaica. The broad host spectrum reported for Anthracoidea sempervirentis, including 12 Carex species of the section Aulocystis in Europe, China, and Japan (Vánky 2012; Denchev et al. 2013) suggests that multiple species may be hidden within that species name. In the molecular studies of Hendrichs et al. (2005; confirmed here), Anthracoidea sempervirentis on Carex ferruginea Scop., C. firma Host, and C. sempervirens formed a monophyletic lineage, but with significant genetic divergence between (single) accessions on different hosts, indeed suggesting cryptic speciation within this species. Disentangling this complex is left open for future studies.

Genetic data are currently available for three of the seven recognized Anthracoidea species on sedges of the section Aulocystis. In the molecular phylogenetic analyses, Anthracoidea sempervirentis on Carex ferruginea, C. firma, and $C$. sempervirens form an independent lineage. Anthracoidea misandrae is a member of the same Anthracoidea subclade, but is not directly related to A. sempervirentis, indicating that they did not evolve from one and the same ancestral species. Anthracoidea pamiroalaica is, in turn, distantly related to $A$. misandrae and A. sempervirentis and additionally belongs to a different Anthracoidea subclade (Fig. 1). The closest phylogenetic relatives of Anthracoidea pamiroalaica resolved in the molecular analyses are A. baldensis (on Carex baldensis L.), A. rupestris (on C. rupestris All.), A. capillaris (on C. capillaris L.), and $A$. vankyi (on $C$. muricata $\mathrm{L}$.). Interestingly, all these species share a comparatively similar spore morphology, but infect host sedges in different Carex sections, Baldenses Tuck., Rupestres (Tuck.) Meinsh., Chlorostachyae Tuck. ex Meinsh., and Phaestoglochin Dumort., respectively, predominantly in Europe (Nannfeldt 1979; Piatek 2005a; Vánky 2012), and the large inter-specific genetic distances support them as distinct species.

The placement of Anthracoidea pamiroalaica distantly to the remaining sequenced Anthracoidea species on Carex sect. Aulocystis, and the fact that these three Anthracoidea spp. do not form a monophyletic group could suggest that radiation of
Anthracoidea was (at least partly) realized in a different way than the hypothesized parallel fungus-host evolution (Kukkonen 1963). Alternatively, the traditional morphological classification of host sedges within the section Aulocystis (Egorova 1999) does not reflect evolutionary relations. Indeed, in the molecular studies of Carex subgenus Carex employing ITS sequences, the analysed sedges of the sect. Aulocystis were non-monophyletic and dispersed within the phylogenetic tree (Hendrichs et al. 2004), but C. koshewnikowii has not been included in molecular studies yet. Recent co-phylogenetic reconstructions of Anthracoidea spp. and host sedges suggested host-shift speciation in this smut genus (Escudero 2015); that study, however, included only 28 Anthracoidea (and two undescribed) species for which sequences were available (Hendrichs et al. 2005; Savchenko et al. 2013), i.e., only $25 \%$ of all described species. Therefore, it is a challenge for future studies to include in molecular phylogenetic analyses the remaining described Anthracoidea spp., including those on host sedges in sect. Aulocystis, and to conduct similar co-phylogenetic analyses with as much smut and host species as possible.

Acknowledgments We thank Anna Latkiewicz (Kraków, Poland) for her assistance with the SEM micrographs. This study was partly supported by the W. Szafer Institute of Botany of the Polish Academy of Sciences, Kraków, Poland through its statutory fund.

Open Access This article is distributed under the terms of the Creative Commons Attribution 4.0 International License (http:// creativecommons.org/licenses/by/4.0/), which permits unrestricted use, distribution, and reproduction in any medium, provided you give appropriate credit to the original author(s) and the source, provide a link to the Creative Commons license, and indicate if changes were made.

\section{References}

Bauer R, Begerow D, Sampaio JP, Weiß M, Oberwinkler F (2006) The simple-septate basidiomycetes: a synopsis. Mycol Prog 5:41-66

Bauer R, Lutz M, Begerow D, Piątek M, Vánky K, Bacigálová K, Oberwinkler F (2008) Anther smut fungi on monocots. Mycol Res 112:1297-1306

Begerow D, Stoll M, Bauer R (2007[2006]) A phylogenetic hypothesis of Ustilaginomycotina based on multiple gene analyses and morphological data. Mycologia 98:906-916

Breckle SW, Hedge IC, Rafiqpoor MD (2013) Vascular plants of Afghanistan, an augmented checklist. Scientia Bonnensis, Bonn

Castresana J (2000) Selection of conserved blocks from multiple alignments for their use in phylogenetic analysis. Mol Biol Evol 17:540 552

Chlebicki A (2002) Two cypericolous smut fungi (Ustilaginomycetes) from the Thian Shan and their biogeographic implications. Mycotaxon 83:279-286

Denchev CM, Denchev TT (2011a) Anthracoidea eburneae, sp. nov. (Anthracoideaceae). Mycol Balc 8:83-85

Denchev CM, Denchev TT (2011b) Anthracoidea melanostachyae sp. nov. (Anthracoideaceae). Mycol Balc 8:153-155 
Denchev CM, Denchev TT (2012) New records of smut fungi. 7. Mycotaxon 121:425-434

Denchev TT, Denchev CM, Michikawa M, Kakishima M (2013) The genus Anthracoidea (Anthracoideaceae) in Japan and some adjacent regions. Mycobiota 2:1-125

Egorova TV (1999) The sedges (Carex L.) of Russia and adjacent states (within the limits of the former USSR). St.-Petersburg State Chemical Pharmaceutical Academy, St.-Petersburg \& Missouri Botanical Garden Press, St. Louis

Escudero M (2015) Phylogenetic congruence of parasitic smut fungi (Anthracoidea, Anthracoideaceae) and their host plants (Carex, Cyperaceae): cospeciation or host-shift speciation? Am J Bot 102:1108-1114

Felsenstein J (1981) Evolutionary trees from DNA sequences: a maximum likelihood approach. J Mol Evol 17:368-376

He S, Li H, Chang X, Wang S (2011) Anthracoidea maquensis, a new species of smut fungi from China. Mycol Prog 10:53-55

Hendrichs M, Oberwinkler F, Begerow D, Bauer R (2004) Carex, subgenus Carex (Cyperaceae) - a phylogenetic approach using ITS sequences. Plant Syst Evol 246:89-107

Hendrichs M, Begerow D, Bauer R, Oberwinkler F (2005) The genus Anthracoidea (Basidiomycota, Ustilaginales): a molecular phylogenetic approach using LSU rDNA sequences. Mycol Res 109:31-40

Huelsenbeck JP, Rannala B (2004) Frequentist properties of Bayesian posterior probabilities of phylogenetic trees under simple and complex substitution models. Syst Biol 53:904913

Huelsenbeck JP, Ronquist F (2001) MRBAYES: Bayesian inference of phylogenetic trees. Bioinformatics 17:754-755

Huelsenbeck JP, Larget B, Miller RE, Ronquist F (2002) Potential applications and pitfalls of Bayesian inference of phylogeny. Syst Biol 51:673-688

Korbonskaya IAI (1990) Griby Tadzhikistana. Donish, Dushanbe

Krachetovich VI (1963) Osokovye - Cyperaceae J. St-Hil. In: Ovchinnikov PN (ed) Flora Tadzhikskoi SSR, osokovye. 2. Izdatelstvo Akademii Nauk SSSR, Moskwa-Leningrad, pp 10-145

Kukkonen I (1963) Taxonomic studies on the genus Anthracoidea (Ustilaginales). Ann Bot Soc Zool Bot Fenn 'Vanamo' 34(3):1-122

Lazkov GA, Sultanova BA (2011) Checklist of vascular plants of Kyrgyzstan. Norrlinia 24:1-166

Lutz M, Bauer R, Begerow D, Oberwinkler F, Triebel D (2004) Tuberculina, rust relatives attack rusts. Mycologia 96:614-626

Lutz M, Göker M, Piątek M, Kemler M, Begerow D, Oberwinkler F (2005) Anther smuts of Caryophyllaceae: molecular characters indicate host-dependent species delimitation. Mycol Prog 4:225-238

Lutz M, Piątek M, Kemler M, Chlebicki A, Oberwinkler F (2008) Anther smuts of Caryophyllaceae: molecular analyses reveal further new species. Mycol Res 112:1280-1296

Nannfeldt JA (1979) Anthracoidea (Ustilaginales) on Nordic Cyperaceae-Caricoideae, a concluding synopsis. Symb Bot Ups 22(3): $1-41$

Nobis M, Nowak A, Nobis A, Nowak S, Kusza G (2011) Atlas of vascular plants of Tajikistan. 2. Opole Scientific Society, Institute of Botany Jagiellonian University, Studio Impreso Przemysław Biliczak, Kraków-Opole

Nobis M, Nowak A, Nobis A (2013) Stipa zeravshanica sp. nov. (Poaceae), an endemic species from rocky walls of the western Pamir Alai Mountains (middle Asia). Nord J Bot 31:666-675

Nowak A, Nobis M, Nowak S, Nobis A (2014a) Distribution, ecology and conservation status of Dionysia involucrata Zaprjag., an endangered endemic of Hissar Mts (Tajikistan, Middle Asia). Acta Soc Bot Pol 83:123-135

Nowak A, Nowak S, Nobis M, Nobis A (2014b) Vegetation of rock clefts and ledges in the Pamir Alai Mts, Tajikistan (Middle Asia). Cent Eur J Biol 9:444-460
Nowak A, Nowak S, Nobis M, Nobis A (2014c) Vegetation of solid rock faces and fissures of the alpine and subnival zone in the Pamir Alai Mountains (Tajikistan, Middle Asia). Phytocoenologia 44(1-2):81101

Nowak A, Nowak S, Nobis M, Nobis A (2014d) Vegetation of rock crevices of the montane and colline zones in the Pamir Alai and Tian-Shan Mts in Tajikistan (Middle Asia). Plant Biosyst 148:1199-1210

O'Donnell KL (1993) Fusarium and its near relatives. In: Reynolds DR, Taylor JW (eds) The fungal holomorph: mitotic, meiotic and pleomorphic speciation in fungal systematics. CAB International, Wallingford, pp 225-233

Piątek M (2005a) Anthracoidea vankyi (Ustilaginomycetes) in Poland, with a review of its host spectrum and world distribution. Acta Mycol 40:87-93

Piątek M (2005b) Kochmania, a new genus of smut fungi and new records of cypericolous species from Poland and Ukraine. Mycotaxon 92:33-42

Piątek M (2006) Anthracoidea mulenkoi (Ustilaginomycetes), a new cypericolous smut fungus from Pakistan. Nova Hedwigia 83:109116

Piatek M (2012) The identity of Cintractia disciformis: reclassification and synonymy of a southern Asian smut parasitic on Carex sect. Aulocystis. IMA Fungus 3:39-43

Piątek M (2013) The identity of Cintractia carpophila var. kenaica: reclassification of a North American smut on Carex micropoda as a distinct species of Anthracoidea. IMA Fungus 4:103-109

Piatek M (2014) Anthracoidea transberingiana, a new smut species on Carex pauciflora from Beringia. Phytotaxa 174(2):105-110

Piatek M, Mułenko W (2010) The calcareous mires in South-East Poland are home to two rare Anthracoidea species. Acta Mycol 45:175-184

Piątek M, Ruszkiewicz-Michalska M, Mułenko W (2005) Catalogue of Polish smut fungi, with notes on four species of Anthracoidea. Pol Bot J 50:19-37

Piątek M, Lutz M, Smith PA, Chater AO (2011) A new species of Antherospora supports the systematic placement of its host plant. IMA Fungus 2:135-142

Piątek M, Lutz M, Ronikier A, Kemler M, Świderska-Burek U (2012) Microbotryum heliospermae, a new anther smut fungus parasitic on Heliosperma pusillum in the mountains of the European Alpine System. Fungal Biol 116:185-195

Piatek M, Lutz M, Chater AO (2013a) Cryptic diversity in the Antherospora vaillantii complex on Muscari species. IMA Fungus 4:5-19

Piątek M, Lutz M, Kemler M (2013b) Microbotryum silenes-saxifragae sp. nov. sporulating in the anthers of Silene saxifraga in southern European mountains. IMA Fungus 4:29-40

Ronquist FR, Huelsenbeck JP (2003) MRBAYES 3: Bayesian phylogenetic inference under mixed models. Bioinformatics 19:1572-1574

Savchenko KG, Lutz M, Piątek M, Heluta VP, Nevo E (2013) Anthracoidea caricis-meadii is a new North American smut fungus on Carex sect. Paniceae. Mycologia 105:181-193

Savchenko KG, Carris LM, Castlebury LA, Heluta VP, Wasser SP, Nevo E (2014a) Revision of Entyloma (Entylomatales, Exobasidiomycetes) on Eryngium. Mycologia 106:797-810

Savchenko KG, Carris LM, Castlebury LA, Heluta VP, Wasser SP, Nevo E (2014b) Stripe smuts of grasses: one lineage or high levels of polyphyly? Persoonia 33:169-181

Savile DBO (1952) A study of the species of Cintractia on Carex, Kobresia, and Scirpus in North America. Can J Bot 30:410-435

Silvestro D, Michalak I (2010) raxmlGUI: a graphical front-end for RAxML. Available at http://sourceforge.net/projects/raxmlgui/

Stamatakis A (2006) RAxML-VI-HPC: maximum likelihood-based phylogenetic analyses with thousands of taxa and mixed models. Bioinformatics 22:2688-2690 
Stamatakis A, Hoover P, Rougemont J (2008) A rapid bootstrap algorithm for the RAxML web servers. Syst Biol 57:758-771

Vánky K (1979) Species concept in Anthracoidea (Ustilaginales) and some new species. Bot Notiser 132:221-231

Vánky K (1994) European smut fungi. G. Fischer Verlag, Stuttgart-JenaNew York

Vánky K (2002) Illustrated genera of smut fungi, 2nd edn. The American Phytopathological Society, St. Paul

Vánky K (2012) Smut fungi of the world. The American Phytopathological Society, St Paul
Vánky K, Abbasi M (2011) Anthracoidea songorica sp. nov. on Carex songorica from Iran. Rostaniha 12:181-185

Vánky K, Lutz M (2007) Revision of some Thecaphora species (Ustilaginomycotina) on Caryophyllaceae. Mycol Res 111: 1207-1219

Vasighzadeh A, Zafari D, Selçuk F, Hüseyin E, Kurşat M, Lutz M, Piątek M (2014) Discovery of Thecaphora schwarzmaniana on Rheum ribes in Iran and Turkey: implications for the diversity and phylogeny of leaf smuts on rhubarbs. Mycol Prog 13:881892 